\title{
PENINGKATAN MINAT BELAJAR SISWA DENGAN PENDEKATAN INKUIRI PADA PELAJARAN ILMU PENGETAHUAN ALAM (IPA) SEKOLAH DASAR
}

\author{
Rachmat Sahputra \\ Prodi Pend. Kimia, Jurusan P.MIPA, FKIP Untan
}

\begin{abstract}
Increasing Student Interest With Inquiry Approach Lesson In Natural Sciences (IPA) Primary School. Students' interest in learning Natural Sciences (IPA) which is characterized by relatively low less attention and less active students during learning in the classroom. This study is intended as an effort to increase student interest in learning the science subjects. The study was conducted by the method of Classroom Action Research (CAR) conducted an inquiry approach to fourth grade students in public elementary school Tanjung Sari No.18 Nanga Pinoh using instruments such as observation sheets. The data were tested for normality distribution of the observation of the data with the Kolmogorov-Smirnov and Shapiro-Wilk and t-test for the significance of differences in the data each cycle.

The results of the research that has been conducted in two cycles of learning for 22 students in action cycle I gained interest in learning with the percentage of $57.47 \%$. Through the inquiry approach to learning that is done has improved the students' interest in learning science subjects with the results of the data obtained in the second cycle as much as $100 \%$ of students have been interested in the science lessons, characterized by high enthusiasm to learn and actively take part in the experiment are taught. Thus through the inquiry approach has been able to increase student interest, especially in natural science subjects and can improve the process.
\end{abstract}

Keywords: Interest in learning, inquiry approach, Lesson in natural sciences.

Peneliti melakukan pengumpulan data awal di SDN No. 18 Tanjung Sari Nanga Pinoh pada tanggal 17 September 2012 hingga 17 Desember 2012 untuk melihat beberapa pernasalahan di dalam kelas pada saat siswa dan guru melakukan proses pembelajaran. Perhatian peneliti diantaranya adalah terhadap siswa kurang bersemangat atau berminat dalam mengikuti pelajaran. Hal ini diduga karena saat menyampaikan pelajaran guru menggunakan model pembelajaran kurang variatif berupa ceramah dan sedikit tanya jawab. Pengamatan terhadap 22 siswa di kelas IV SDN No. 18 Tanjung Sari diperoleh data $21,73 \%$ yang memiliki minat belajar yang baik dan 78,26\% siswa mendapat nilai dibawah standar KKM. Rendahnya hasil belajar tersebut diduga akibat rendahnya minat siswa dalam proses pembelajaran. Data hasil pengamatan 
awal tersebut mendorong peneliti untuk dapat meningkatkan minat belajar siswa dengan mengembangkan model pembelajaran dengan pendekatan inquiri yang diharapkan sebagai upaya yang dapat meningkatkan hasil belajar siswa.

Kata minat (interest) yang berarti menarik atau tertarik. Menurut Slameto (dalam Ardiansyah, 2011) minat pada dasarnya adalah penerimaan akan suatu hubungan antara diri sendiri, dengan sesuatu dari luar, semakin kuat dan dekat hubungan tersebut, semakin besar minat. Slameto (dalam Ardiansyah, 2011) menyatakan minat adalah kecenderungan untuk tetap memperhatikan dan menikmati beberapa kegiatan. Slameto sendiri mendefinisikan sebagai rasa suka dan rasa ketertarikan pada suatu hal atau sesuatu tanpa ada yang menyuruh.

Shaleh dan Wahab (dalam Adriansyah,2011) mendefinisikan minat sebagai suatu kecenderungan untuk memberikan perhatian dan bertindak terhadap orang, aktivitas atau situasi yang menjadi obyek minat tersebut dengan disertai perasaan senang. Minat erat hubungannya dengan rasa suka atau tidak suka seseorang terhadap sesuatu tindakan. Minat pada dasarnya adalah penerimaan akan suatu hubungan antara diri sendiri dengan sesuatu di luar diri. Semakin kuat atau dekat hubungan tersebut, semakin besar minatnya. Sardiman (dalam Ardiansyah, 2011) berpendapat bahwa minat diartikan sebagai suatu kondisi yang terjadi apabila seseorang melihat ciri-ciri atau arti sementara situasi yang dihubungkan dengan keinginankeinginan atau kebutuhankebutuhannya sendiri.
Beberapa pengertian di atas dapat disimpulkan bahwa minat adalah kecenderungan seseorang terhadap obyek atau sesuatu kegiatan yang digemari yang disertai dengan perasaan senang, adanya perhatian, dan keaktifan berbuat. Minat mengandung unsur kognisi (mengenal), emosi (perasaan), dan konasi (kehendak). Unsur kognisi dari minat didahului oleh pengetahuan dan informasi mengenai obyek yang dituju oleh minat tersebut, ada unsur emosi karena dalam partisipasi atau pengalaman itu disertai oleh perasaan tertentu, seperti rasa senang (emosi), sedangkan unsur konasi merupakan kelanjutan dari unsur kognisi. Dari ketiga unsur inilah yang diwujudkan dalam bentuk kemauan dan hasrat untuk melakukan suatu kegiatan, termasuk kegiatan yang ada di sekolah seperti belajar.

Berdasarkan cara

mengungkapkannya, minat dapat dibedakan menjadi empat yaitu: expressed interest, manifest interest, tested interest dan inventoried interest: (1) Expressed Interest (minat yang diekspresikan) adalah minat yang diungkapkan dengan cara meminta kepada subyek untuk menyatakan atau menuliskan kegiatan; (2) Manifest Interest (minat yang diwujudkan) adalah minat yang diungkapkan dengan cara mengobservasi atau melakukan pengamatan secara langsung terhadap aktivitas-aktivitas yang dilakuk:an subyek atau dengan mengetahui hobinya; (3) Tested Interest adalah minat yang diungkapkan dengan cara menyimpulkan dari jawaban hasil tes obyektif yang diberikan, nilainilai yang tinggi pada suatu 
obyek biasanya menunjukkan minat yang tinggi. (4). Inventoried Interest adalah minat yang diungkapkan dengan menggunakan alat-alat yang sudah distandarkan, dimana biasanya berisi pertanyaan-pertanyaan yang ditujukan kepada subyek apakah ia senang atau tidak senang terhadap sejumlah obyek yang ditanyakan.

Aspek-Aspek Minat menurut Hurlock (dalam Ardiansyah, 2011) terbagi dalam dua aspek, yaitu aspek kognitif dan aspek afektif. Dalam aspek ini nantinya akan diketahui indikator peningkatan minat siswa dalam belajar Ilmu Pengetahuan Alam. (1) Aspek kognitif, minat berdasarkan atas konsep yang dikembangkan anak mengenai bidang yang terkait dengan minat, misalnya aspek kognitif dari minat anak terhadap mata pelajaran tertentu. Bagian-bagian dari aspek kognitif yaitu kebutuhan akan informasi dan rasa ingin tahu. (2) Aspek afektif, minat berkembang dari pengalaman pribadi yang berasal dari lingkungan keluarga maupun sekolah. Lingkungan belajar akan lebih berpengaruh kepada suasana belajar di kelas maupun di luar kelas. Kedua aspek minat (aspek kognitif dan aspek afektit) di atas sangat mempengaruhi prestasi belajar siswa, seperti yang diungkapkan Muhibbin Syah (dalam Ardiansyah, 2011) yang menyatakan pada dasamya minat seseorang dapat mempengaruhi kualitas pencapaian hasil belajar siswa dalam bidangbidang tertentu.

\section{Pendekatan inkuiri pertama}

yang memandang hakikat belajar sebagai latihan berpikir melalui pertanyaan- pertanyaan. Suchman mengemukakan inti gagasan pendekatan inkuiri adalah (1) siswa akan bertanya (inquire) bila mereka dihadapkan pada masalah yang membingungkan, kurang jelas atau kejadian aneb (discrepant event); (2) siswa memiliki kemampuan untuk menganalisis strategi berpikir mereka; (3) strategi berpikir dapat diajarkan dan ditambahkan kepada siswa, dan (4) inkuiri dapat lebih bermakna dan efektif apabila dilakukan dalam konteks kelompok.

Inkuiri adalah suatu proses untuk memperoleh dan mendapatkan informasi dengan melakukan observasi dan atau eksperimen untuk mencari jawaban atau memecahkan masalah terhadap pertanyaan atau rumusan masalah dengan menggunakan kemampuan berpikir kritis dan logis. Sedangkan National Science Education Standards (NSES) mendefinisikan inkuiri sebagai aktivitas beraneka ragam yang meliputi observasi, membuat pertanyaan, memeriksa buku-buku atau sumber infornasi lain untuk melihat apa yang telah diketahui; merencanakan investigasi; memeriksa kembali apa yang telah diketahui menurut bukti eksperimen; menggunakan alat untuk mengumpulkan, menganalisa, dan menginterpretasikan data, mengajukan jawaban, penjelasan dan prediksi, serta mengkomunikasikan hasil.

Dasar Penggunaan Model Pembelajaran Inkuiri menurut Edi Hendri Mulyana (2012) mengemukakan bahwa model pembelajaran inkuiri dipandang sebagai model yang diasumsikan cukup akomodatif bagi penyelenggaraan pembelajaran sains di sekolah dasar sekarang ini. Alasannya model ini menjembatani keadaan 
transisi dari gaya pengajaran sains konvensional yang masih verbalistis serta minim alat-alat, ke gaya pengajaran sains altematif yang lebih proporisonal bagi hakikat sains dan karakteristik siswa sekolah dasar. Selain itu, model pembelajaran ini mendukung empat karakteristik siswa, yaitu: (1) Secara instinktif siswa selalu ingin tahu; (2) Di dalam percakapan, siswa selalu ingin berbicara dan mengkomunikasikan idenya;

Dalam membangun (kontruksi) pengetahuan, siswa selalu ingin membuat sesuatu; (4) Siswa selalu mengekspresikan diri;

Perkembangan intelektual siswa SD berada pada jenjang operasional konkret; dan (5) Perkembangan sosial siswa SD berada pada fase bermain.

Gulo (dalam Trianto, 2009: 168) menyatakan, bahwa inkuiri tidak hanya mengembangkan kemampuan intelektual tetapi seluruh potensi yang ada, termasuk pengembangan emosional dan keterampilan inkuiri merupakan suatu proses yang bermula dari merumuskan masalah, merumuskan hipotesis, mengumpulkan data dengan merancang percobaan, menganalisis data, dan membuat kesimpulan. Ilmu Pengetahuan Alam (IPA) berhubungan dengan cara mencari tahu tentang alam secara sistematis, sehingga IPA bukan hanya penugasan kumpulan pengetahuan yang berupa fakta-fakta, konsepkonsep, atau prinsip-prinsip saja tetapi juga merupakan suatu proses penemuan, Proses pembelajarannya menekankan pada pemberian pengalaman langsung untuk mengembangkan kompetensi agar menjelajahi dan memahami alam sekitar secara ilmiah.
Mata Pelajaran IPA di Sekolah Dasar bertujuan agar siswa: memahami konsep- konsep IPA, memiliki keterampilan proses, mempunyai minat mempelajari alam sekitar, bersikap ilmiah, mampu menerapkan konsep- konsep IPA untuk menjelaskan gejala-gejala alam dan memecahkan masalah dalam kehidupan sehari-hari, mencintai alam sekitar, serta menyadari kebesaran dan keagungan Tuhan. Carin dan Sund (dalam Badarudin, 2011) memberikan petunjuk tentang bagaimana seharusnya IPA diajarkan pada pendidikan dasar. Salah satu diantaranya adalah menanamkan ke dalam diri siswa keingintahuan akan alam sekitar, serta dapat memahami pejelasanpenjelasan ilmiah tentang fenomena alam. Hal ini sesuai dengan salah satu tujuan pendidikan IPA yaitu bahwa IPA harus mampu memberikan pengetahuan kepada siswa tentang dunia dimana kita hidup, dan bagaimana kita sebagai makhluk hidup harus bersikap terhadap alam. Mechling dan Oliver (dalam Badarudin, 2011) mengemukakan bahwa penekanan yang diberikan dalam pengajaran keterampilan proses IPA adalah pada keterampilan berpikir. Keterampilan berpikir ini dapat berkembang pada anak selama anak diberi kesempatan untuk berlatih menggunakan keterampilantersebut.

\section{Metode}

1. Waktu dan Tempat Penelitian Waktu penelitian ini dilaksanakan pada bulan April 2013 diminggu kedua, kemudian dilanjutkan pada minggu ketiga bulan April 2013, pengolahan data 
pada bulan Mei 2013. Tempat Penelitian dilaksanan pada Sekolah Dasar Negeri No. 18 Tanjung Sari Nanga Pinoh kabupaten Melawi Kalimantan Barat.

2. Subjek dan Objek Penelitian Subjek dalam penelitian adalah seluruh siswa kelas IV Sekolah Dasar Negeri No. 18 Tanjung Sari tahun ajaran 20122013 dengan jumlah siswa sebanyak 22 orang, terdiri dari 5 orang siswa perempuan dan 17 orang siswa laki-laki. Sedangkan yang menjadi objek dalam penelitian ini adalah peningkatan minat belajar dengan pendekatan inkuiri pada pelajaran ilmu pengetahuan alam (IPA).

3. Prosedur Penelitian

Prosedur penelitian ini menggunakan metode Penelitian Tindakan Kelas yang meliputi empat komponen yaitu, perencanaan (planning), tindakan (action), pengamatan (observing), dan refleksi (reflecting), Tahapan Perencanaan (Planning). Semua tahapan tersebut dilakukan dalam beberapa siklus. Tahap Perencanaan pada setiap siklus dilakukan dengan membuat Rencana Pelaksanaan Pembelajaran (RPP), menyiapkan media yang akan digunakan dalam proses pembelajaran, membuat lembar observasi Minat siswa, dan menyiapkan lembar kerja siswa. Tahap Pelaksanaan tindakan pada setiap siklus dilakukan dengan membagi siswa dalam 3 kelompok, mengajukan permasalahan yang harus di pecahkan siswa, Meminta siswa untuk mengajukan dan menuliskan hipotesis, meminta masing-masing kelompok untuk mengerjakan tugas dan mengumpulkan data-data, memberikan kesempatan bertanya pada setiap kelompok mengenai langkahlangkah dalam penyelesaian tugas kelompok, meminta perwakilan kelompok masing-masing mempresentasikan hasil kerja kelompoknya di depan kelas, dan meminta siswa menyimpulkan hasil tugas kelompoknya.

Tahap Observasi setiap siklus menggunakan lembar observasi untuk melihat aspek minat siswa pada saat pembelajaran. Tahapan refleksi setiap siklus dilakukan setelah diperoleh hasil observasi kemudian hasil observasi dikumpulkan dan dianalisis untuk melihat keberhasilan yang telah diperoleh atau kekurangan-kekurangan maupun hambatan yang masih dihadapi dalam tindakan yang telah dilakukan. Hasil refleksi ini akan dijadikan sebagai acuan untuk penyempurnaan dalam melakukan atau melaksanakan tahapan siklus selanjutnya

4. Analisis Data

Analisis data dilakukan dengan membandingkan data hasil minat belajar siswa pada setiap siklusnya yang diperoleh dari data pengamatan dengan lembar observasi. Data hasil observasi diuji normalitas sebaran data dengan uji Kolmogorov-Smirnov dan Shapiro-Wilk serta dilakukan uji t untuk melihat signifikansi perbedaan data siklus I dan siklus II. 


\section{Hasil dan Pembahasan}

Penelitian tindakan kelas dilakukan dengan dua siklus. Setiap siklus Penelitian Tindakan Kelas dimulai dengan tahap perencanaan dengan menyiapkan seperangkat pembelajaran yang mendukung pelaksanaan tindaka berupa rencana pelaksanaan pembelajaran, lembar observasi lembar kerja siswa, mempersiapkan media atau peralatan yang akan digunakan dalam proses pembelajaran. Tahapan pelaksanaan tindakan di dalam kelas dimulai dengan guru mengucapkan salam, mengajak siswa untuk berdoa sesuai kepercayaannya masing-masing dan melakukan absensi. Setelah itu guru menceritakan sedikit tentang materi yang akan diajarkan, serta tujuan dari pembelajaran yang diharapkan yaitu diantaranya agar siswa dapat mengetahui dan dapat menjelaskan pengertian dari sumber daya alam, agar siswa dapat memahami manfaat sumber daya alam untuk kehidupan sehari-hari, dan agar siswa dapat membuat atau menghasilkan benda sederhana yang berasal dari sumber daya alam yang ada di sekitar.

Tahap pelaksanaan inkuiri yaitu pada kegiatan eksplorasi dengan pertanyaan kepada siswa tentang sumber daya alam kemudian menjelaskan penjabaran materi sumber daya alam. Kegiatan elaborasi dengan melakukan percobaan yang dilakukan. Kegiatan konfirmasi ditandai dengan memberi kesempatan siswa untuk menyimpulkan serta mempresentasikan hasil kerja kelompoknya ke depan kelas. Tahap Observasi setiap siklus dengan melakukan pengamatan terhadap minat belajar siswa Pengamatan tersebut menjadi dasar dalam menentukan penskoran terhadap minat belajar siswa dan menghitung peningkatan minat belajar setiap siklus.

Tahap Refleksi setiap siklus dilakukan setelah pembelajaran terhadap hasil observasi dan melakukan perbaikan untuk perencanaan PTK berikutnya. Hasil observasi yang dilakukan selama pelaksanaan tindakan siklus I dan siklus II ditampilkan pada Tabel I. Data observasi pada siklus I tingkat minat belajar menunjukkan perkembangan yang baik dibandingkan dengan data awal prapenelitian, selanjutnya penelitian diteruskan dengan tahap siklus II. Siklus II dilakukan setelah melakukan evaluasi dan perbaikan tindakan sikus I sebelumnya dan diperoleh data basil observasi minat siswa pada siklus I dan II yang dapat ditampilkan pada Tabel 1.

Kriteria pemberian nilai pada aspek minat sebagai berikut:

1. Aspek kesungguhan siswa: (1) Skor 1 pada aspek minat kesungguhan siswa artinya kesiapan belajar; (2) Skor 2 pada aspek kesungguhan siswa arinya kesiapan belajar, keseriusan menerima pelajaran; (3) Skor 3 pada aspek minat perasaan senang artinya kesiapan belajar, keseriusan menerima pelajaran,respon rasa senang; (4) Skor 4 pada aspek minat kesungguhan artinya kesiapan belajar, keseriusan menerima pelajaran, respon rasa senang, dan konsentrasi.

2. Aspek minat pad.a perhatian siswa sebagai berikut: (1) Skor 1 pada aspek minat perhatian 
siswa artinya siswa bertanya dengan teman; (2) Skor 2 pada aspek minat perhatian siswa artinya siswa bertanya dengan teman dan bertanya dengan guru; (3) Skor 3 pada aspek minat perhatian siswa artinya siswa bertanya dengan teman, bertanya dengan guru dan membaca buku; (4) Skor 4 pada aspek minat perhatian siswa artinya siswa bertanya kepada teman, bertanya dengan guru. membaca buku dan memperhatikan perintah guru dan mencatat.
3. Aspek minat pada keaktifan berbuat siswa sebagai berikut: (1) Skor pada aspek minat keaktifan berbuat siswa artinya siswa menyebutkan; (2) Skor 2 pada aspek minat keaktifa berbuat siswa artinya siswa menyebutkan dan menulis; (3) Skor 3 pada aspek minat keaktifan berbuat siswa artinya siswa menyebutkan, menulis dan mengerjakan tugas; (4) Skor 4 pada aspek minat keaktifan berbuat siswa artinya siswa menyebutkan, menulis, mengerjakan tugas dan melaksanakan perintah.

Tabel 1. Hasil observasi minat siswa siklus I dan siklus II

\begin{tabular}{|c|c|c|c|c|c|c|c|c|c|}
\hline \multirow{3}{*}{ No } & \multirow{3}{*}{$\begin{array}{l}\text { Inisial } \\
\text { Siswa }\end{array}$} & \multicolumn{6}{|c|}{ Aspek Minat Belajar } & \multirow{2}{*}{\multicolumn{2}{|c|}{ Ativitas (\%) }} \\
\hline & & \multicolumn{2}{|c|}{ Kesungguhan } & \multicolumn{2}{|c|}{ Perhatian } & \multicolumn{2}{|c|}{ Keaktifan } & & \\
\hline & & Siklus I & Siklus II & Siklus I & Siklus II & Siklus I & Siklus II & Siklus I & Siklus II \\
\hline 1 & $\mathrm{AH}$ & 2 & 3 & 1 & 2 & 1 & 3 & 33 & 66 \\
\hline 2 & $\mathrm{AAC}$ & 2 & 3 & 2 & 4 & 1 & 3 & 41 & 83 \\
\hline 3 & $\mathrm{ABA}$ & 2 & 3 & 2 & 3 & 2 & 3 & 50 & 75 \\
\hline 4 & $\mathrm{AS}$ & 1 & 3 & 3 & 4 & 3 & 3 & 58 & 83 \\
\hline 5 & $\mathrm{BF}$ & 3 & 4 & 2 & 3 & 3 & 4 & 66 & 91 \\
\hline 6 & DPS & 1 & 3 & 2 & 3 & 2 & 3 & 41 & 75 \\
\hline 7 & DR & 3 & 4 & 2 & 3 & 4 & 4 & 75 & 91 \\
\hline 8 & Ef & 1 & 3 & 2 & 3 & 2 & 3 & 41 & 75 \\
\hline 9 & ER & 3 & 3 & 2 & 3 & 3 & 3 & 66 & 75 \\
\hline 10 & FS & 2 & 3 & 2 & 3 & 2 & 3 & 50 & 75 \\
\hline 11 & JEP & 1 & 2 & 1 & 3 & 1 & 3 & 25 & 66 \\
\hline 12 & $\mathrm{KS}$ & 2 & 3 & 1 & 3 & 2 & 2 & 41 & 66 \\
\hline 13 & MY & 1 & 3 & 1 & 3 & 1 & 3 & 25 & 75 \\
\hline 14 & PR & 2 & 3 & 1 & 3 & 2 & 3 & 41 & 75 \\
\hline 15 & Pry & 3 & 4 & 2 & 4 & 3 & 3 & 66 & 91 \\
\hline 16 & SRR & 2 & 3 & 3 & 3 & 1 & 4 & 50 & 83 \\
\hline 17 & LR & 2 & 3 & 2 & 3 & 2 & 2 & 50 & 66 \\
\hline 18 & $\mathrm{RN}$ & 1 & 2 & 1 & 3 & 1 & 3 & 25 & 66 \\
\hline 19 & RY & 2 & 3 & 2 & 3 & 2 & 3 & 50 & 75 \\
\hline 20 & RR & 3 & 3 & 1 & 2 & 2 & 3 & 50 & 66 \\
\hline 21 & YTM & 1 & 2 & 2 & 3 & 2 & 3 & 41 & 66 \\
\hline 22 & EP & 1 & 3 & 2 & 2 & 2 & 3 & 41 & 66 \\
\hline \multicolumn{2}{|c|}{ Jumlah } & 41 & 66 & 39 & 66 & 40 & 67 & & \\
\hline \multicolumn{2}{|c|}{$\begin{array}{l}\text { Komponen } \\
\text { Minat (\%) }\end{array}$} & 46,59 & 75,00 & 44,31 & 75,00 & 50,00 & 76,13 & & \\
\hline
\end{tabular}

Keterangan:

1=Kurang Baik; 2=Cukup; 3=Baik; 4=Sangat Baik. 
Uji normalitas terhadap data basil observasi siklus I dan siklus II dilakukan untuk melihat kenormalan sebaran datanya. Pengujian dilakukan dengan uji kolmogorov-Smirnov dan Shapiro-Wilk.

Tabet 2. Uji normalitas

\begin{tabular}{lcccccc}
\hline \multirow{2}{*}{ Uji Normalitas } & \multicolumn{2}{c}{ Kolmogorov-Smirnov } & \multicolumn{3}{c}{ Shapiro-Wilk } \\
\cline { 2 - 7 } Data & Statistic & df & Sig. & Statistic & df & Sig. \\
\hline Siklus I & .176 & 22 & .076 & .931 & 22 & .131 \\
\hline Siklus II & .227 & 22 & .004 & .836 & 22 & .002 \\
\hline
\end{tabular}

a. Lilliefors Significance Correction

Tabel 2 menunjukkan bahwa signifikansi data kurang dari 0,500 yang menunjukkan bahwa sebaran data basil observasi siklus I dan siklus II terdistribusi normal dan dapat dilanjutkan dengan menguji $\mathrm{t}$ untuk melihat perbedaan rata-rata data siklus I dan siklus II.

Uji $\mathrm{t}$ dilakukan untuk melihat perbedaan data rata-rata basil minat siswa pada siklus I dan siklus II yang diperoleh dari data observasi yang ditampilkan pada Tabel 3 .

Tabet 3 Data hasil uji t

\begin{tabular}{ccccccc}
\hline \multicolumn{7}{c}{$95 \%$ Confidence Interval of the Difference } \\
\hline Uji t Data & $\mathrm{t}$ & df & Sig. (2-tailed) & $\begin{array}{c}\text { Mean } \\
\text { Difference }\end{array}$ & Lower & Upper \\
\hline Siklus I & - & 21 & .000 & -48.3636 & -54.436 & -42.291 \\
\hline Siklus II & - & 21 & .000 & -20.0000 & -23.880 & -16.120 \\
\hline
\end{tabular}

Tabel 3 menunjukkan bahwa signifikansi dua sisi dengan nilai signifikansi 0,000 yang menunjukkan bahwa rata-rata nilai minat siswa pada siklus I dan siklus II memiliki perbedaan yang signifikan.

Data Tabel 1 menunjukkan

siklus II lebih tinggi dibandingkan minat belajar siswa pada siklus II. Peningkatan minat belajar siswa dengan komponen kesungguhan, perhatian dan keaktifan siswa disajikan dalam Gambar 1 .

bahwa minat belajar siswa pada

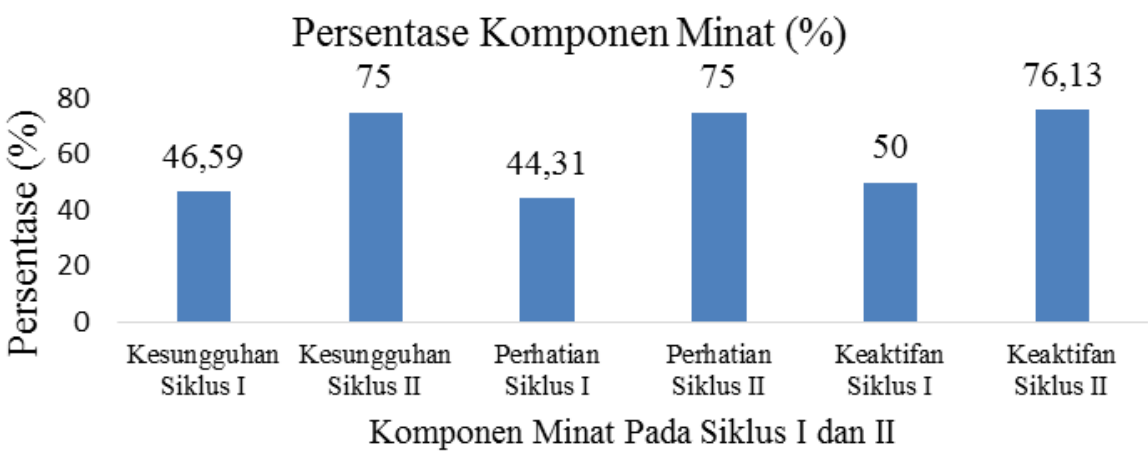

Gambar 1. Persentase komponen minat belajar siswa siklus I dan II 
Komponen minat belajar siswa pada siklus I dan siklus II meningkat dari $46,59 \%$ menjadi $75,00 \%$. Perhatian siswa telah meningkat dari $44,31 \%$ menjadi $75,00 \%$, sedangkan komponen keaktifan belajar siswa telah meningkat dari 50,00\% menjadi $76,13 \%$.
Hasil tindakan kelas diatas dapat memberi verifikasi hasil yang diambil dari hasil observasi minat belajar siswa dari siklus I dan siklus II. Dibawah ini merupakan tabel perbandingan peningkatan minat belajar siswa yang diperoleh oleh siswa dari hasil observasi ditiap siklus.

Tabel 4. Perbandingan Minat Belajar Siswa pada Siklus I dan Siklus II

\begin{tabular}{ccccc}
\hline No & Siklus & Jumlah siswa & $\begin{array}{c}\text { Persentase Pencapaian } \\
\text { Minat Belajar }\end{array}$ & Keterangan \\
\hline 1 & Data Awal & 5 & $21,73 \%$ & Belum Berminat \\
\hline 2 & Siklus I & 11 & $50,00 \%$ & Berminat \\
\hline 3 & Siklus II & 22 & $100,00 \%$ & Sangat Berminat \\
\hline
\end{tabular}

Tabel 4 menunjukkan bahwa skor minatbelajar siswa pada siklus I meningkat dari data awal yang didapatkan yaitu dari $21,73 \%$ menjadi $50,00 \%$ dengan peningkatan sebesar $28,27 \%$ dengan peningkatan jumlah siswa yang berminat dari jumlah 5 orang siswa menjadi 11 orang siswa. Kemudian pada siklus II minat belajar siswa meningkat dari $50,00 \%$ (11 siswa) menjadi 100\% (22 siswa). Sehingga hasil observasi penelitian menunjukkan bahwa pendekatan inquiri dalam pembelajaran IPA telah meningkatkan minat belajar siswa.

\section{Simpulan dan Saran}

Peningkatan minat belajar siswa dengan pendekatan inkuiri pada pembelajaran Ilmu Pengetahuan Alam (IPA) SD yang dilakukan melului penelitian tindakan kelas di kelas IV Sekolah Dasar Negeri No. 18 Tanjung Sari Nanga Pinoh tahun pelajaran 2012/2013 di semester II telah menunjukkan bahwa proses pembelajaran telah mengalami peningkatan dari data awal $21,73 \%$ siswa belum berminat menjadi 50,00\% pada siklus I dan terus meningkat menjadi $100 \%$ siswa berminat terhadap pelajaran IPA pada siklus II.

Berdasarkan hasil penelitian tindakan kelas pada pembelajaran IPA yang telah dilaksanakan masih perlu diupayakan dengan kreasi guru untuk membuat media dan peralatan pembelajaran untuk memperbaiki fasiltas dan peralatan yang tidak dimiliki sekolah serta perlu pengembangan model pembelajaran baru untuk terus meningkatkan minat belajar siswa.

\section{Daftar Pustaka}

Ardiansyah, A. 2011. Hakikat Minat Belajar. Malang: Kabar Pendidikan.

Badarudin, 2011. Hakikat IPA di SD (online) tersedia http://ayahalby.wordpress.com /2011/02/2 2/hakikat-ipa-di-sd/. (Tanggal buka 14 April 2013). 
10 Jurnal Pendidikan Matematika dan IPA Vol. 4. No. 2. Juli 2013: 1-10

Edi Hendri Mulyana, 2012. Model Pembelajaran lnquiri (online) tersedia: http://www.dinamikaedukasida sar.org/ (Tangggal buka 14 April 2013)
Trianto, 2009. Mendesain Model Pembelajaran Inovatif-Progresif Kencana Prenanda Media Group : Jakarta. 